\title{
PERFORMANCE OF ISLAMIC LAW IN INDONESIA IN THE FIELDS OF CIVIL, PRIVATE LAW, PUBLIC LAW AND ETHICS
}

\author{
Zarul Arifin \\ Faculty of Sharia, Islamic Institute of Sultan Muhammad Syafiuddin Sambas \\ zarularifin89@gmail.com
}

\begin{abstract}
Abstrak. Wacana tentang hubungan Islam dan negara masih menjadi pembahasan yang menarik. Masalahnya, Indonesia negara yang mayoritas warganya beragama Islam tidak menjadikan hukum Islam sebagai dasar konstitusinya, namun Indonesia juga bukan negara sekuler. Indonesia dapat dikatakan sebagai negara yang moderat, dimana hukum ketatanegaraan tidak bertentangan dengan hukum Islam Hukum Islam di tengah masyarakat Indonesia mempunyai kedudukan yang lebih penting dari pada dua ciri hukum lainnya yaitu hukum positif dan hukum hukum, tetapi tentunya tidak secara normatif atau ideologis. rasa ordogmatis, lebih secara tekstual tetapi secara kultural. Islam sebagai agama yang dianut oleh mayoritas penduduk Indonesia tentunya sangat mempengaruhi gaya hidup bangsa Indonesia. Dalam pandangan masyarakat Indonesia, hukum Islam merupakan bagian penting dari ajaran agama dan Islam merupakan ruang utama ekspresi pengalaman beragama dan menentukan keberlangsungan serta identitas sejarahnya.
\end{abstract}

Kata kunci: Kinerja, Hukum Islam, Indonesia.

\begin{abstract}
The discourse on the relationship between Islam and the state is still being discussedwhich are interesting. The problem is that Indonesia is a country with a majority of its citizensbeing Muslim does not make Islamic law the basis of its constitution.However, Indonesia is also not a secular country. Indonesia cansaid to be a moderate country, where the constitutional law does not contradict Islamic lawIslamic law in the midst of Indonesian society has a positionwhich is more important than the two other legal features, positive law and lawadat, but certainly not in a normative or ideological sense ordogmatic, more so textually but culturally. Islam, as the religion embraced by the majority of Indonesia's population, certainly greatly influences the lifestyle of the Indonesian nation. In the view of Indonesian society, Islamic law is an important part of religious teachings and Islam is a space for the main expression of religious experience and determines its continuity and historical identity.
\end{abstract}

Keywords: Performance, Islamic Law, Indonesia. 


\section{INTRODUCTION}

In essence, Islamic teachings cover various dimensions, including theological, spiritual, moral, historical, cultural, political, legal, and scientific dimensions. ${ }^{1}$ He emphasized that Islam does not only regulate the issue of ritual worship in a vertical relationship with God alone, but it also regulates human relations in social interactions. ${ }^{2}$

Regarding social interaction in the legal dimension, Muslims are required to implement the teachings they carry. Therefore, the existence of Islamic law is to regulate human interaction in social life. Islamic law has two functions, namely as a regulator of community life or social control, and as a form of society or social engineering. ${ }^{3}$

The passion for studying Islamic law in Indonesia in the last decade is very encouraging due to many factors. The

\footnotetext{
${ }^{1}$ Harun Nasution, Islam Ditinjau dari Berbagai Aspeknya, Jilid I (Cet. V ; Jakarta : Universitas Indonesia Press, 1985), p. 4

${ }^{2}$ Yoseph Schachat, An Introduction to Islamic Law (Oxford : Oxford University Press, 1964), p. 1

${ }^{3}$ Amir Syarifuddin, Meretas Jihad ; Isu-Isu Penting Hukum Islam Kontemporer di Indonesia (Cet. I ; Jakarta : Ciputat Press, 2002), p. 3
}

sense of diversity among Muslims shows an increasing tendency, so that awareness of the activities and obligations of carrying out Islamic teachings, which are believed to be the outpouring of the grace of God's love for the universe, has also increased. Islamic law is an integral part of Islamic teachings that cannot be separated or separated from the life of Muslims, on the basis of their Islamic beliefs. ${ }^{4}$

Islamic law as the legal system in Indonesia has had a lot of influence and impact in various fields of life for Indonesian society. These impacts and influences can be seen in the fields of worship, private law, public law and ethics. This fact proves that various fields in the life of Indonesian society have absorbed the norms of Islamic law. Based on the description above, the authors in the discussion of this paper draw some formulations and problem limitations, namely: How is the

\footnotetext{
${ }^{4}$ Ahmad Azhar Basyir, Refleksi Atas Persoalan Keislaman ; Seputar Filsafat, Hukum, Politik dan Ekonomi (Cet. IV ; Bandung : Mizan, 1996), p. 141
} 
absorption of Islamic law in the field of worship in Indonesia?. How is the absorption of Islamic law in the field of public law in Indonesia ?. How is the absorption of Islamic law in the field of private law in Indonesia? How is the absorption of Islamic law in the field of ethics in Indonesia?

\section{METHOD}

This research is a normative or doctrinal legal research that is carried out by method under the unique character of jurisprudenceandis different from social science or natural science. ${ }^{5}$ Doctrinal research is research that provides a systematic explanation of the provisions governing certain areas of law, analyzes the relationship between these provisions, explains the problem, and perhaps, predicts its development. ${ }^{6}$

\footnotetext{
${ }^{5}$ Depri Liber

"MetodePenelitianHukumNormatif Empiris: Karakteristik Khas MetodeMenelitiHukum," Fiat JurnalImuHukum 8, no. 1 (2017): 25.

${ }^{6}$ Terry Hutchinson, Researching and Writing in Law (Sydney: Lawbook Co, 2002).
}

\section{RESULTS AND DISCUSSION}

\section{A. Absorption of Islamic Law in the \\ Field of Worship in Indonesia}

Islamic law stems from the faith that convinces humans about freedom from all kinds of servitude from other than Allah, the only Almighty. Islamic law develops awareness in human beings who believe in the equality of all humans before Allah. All humans are servants of Allah, just like all other creatures. Humans were chosen by Allah to become caliphs on this earth. It is in Islamic law that moral consciousness is integrated with social consciousness. From this basis, it can be understood that the format of Islamic law is divided into four main areas, one of which is the field of worship, namely concerning the laws that govern the fostering of human relations with their creator, to whom only humans must serve. With the various kinds of worship that are mandated, human moral awareness as well as social awareness is developed. $^{7}$

\footnotetext{
${ }^{7}$ Ali Yafie, Fungsi Hukum Islam dalam Kehidupan Umat, dalam Amrullah Ahmad, Dimensi Hukum Islam Dalam Sistem Hukum
} 
In broad outline, Islamic law can be detailed in three ways: First, guidance and guidance to obtain the correct knowledge of Allah Almighty and the unseen realm that human senses cannot reach. This is called abkam syar'iyyah i'tiqadiyah which is the subject of the science of tauhid (kalam). Second, the guidelines and provisions for the development of potential goodness that exists in man, so that he becomes a real respectable being. This is called abkam syar'iyyah kbuluqiyyah, which is the field of cultivation of Sufism (morals). Third, provisions and a set of legal regulations to organize practical matters (amaliyah) in the way of performing worship to Allah, conducting daily intercourse with fellow human beings in fulfilling life needs, making relationships in the family environment, and carrying out control. general public to ensure justice and the creation of peace in public relations. This field is called abkam syar'iyyah amaliyah, which is the subject of fiqh science. Since this third field concerns

Nasional (Cet. I ; Jakarta : Gema Insani Press, 1996), pp. 93-94 daily real and practical actions, this field dominates the name "Islamic law". ${ }^{8}$

Indonesia is a country where the majority of the population is Muslim, so the rules and regulations that characterize their lives absorb a lot of the teachings of Islamic law. Especially with regard to the field of worship, aspects of Islamic law have significant absorption in shaping and coloring the character and culture of Indonesian society.

The development of National law in a country where the majority of the population is Muslim, it is urgent to pay attention to religious elements. Legal development becomes more urgent if it is linked to the objective needs of developing countries such as Indonesia. This is because the ideals of independence and development have encouraged these countries to always reorganize their societal order, be it in

\footnotetext{
${ }^{8}$ Ali Yafie, Menggagas Fiqih Sosial ; Dari Soal Lingkungan Hidup, Asuransi hingga Ukhuwah (Cet. II ; Bandung : Mizan, 1994), p. 113
} 
the political, economic, social, and especially religious fields. ${ }^{9}$

In Indonesia, Islamic law has been fully accepted and implemented by the Muslim community, even though it is dominated by fiqh Syafi'iyah. This, said Rahmat Djatnika, is that Syafi'iyah fiqh is more numerous and closer to the Indonesian personality, ${ }^{10}$ although for further development other fiqhs have also colored Indonesian society.

The author sees the absorption of Islamic law in Indonesia in the field of worship, that Islam has required various forms of worship that can cleanse one's soul, elevate one's spiritual and physical status, and do not waste human interests to prosper the world. Prayers, fasting, zakat, pilgrimage and other acts of worship are determined for both the individual and the community.

Worship can be classified into community worship and individual worship. Worship in a social context must take precedence over individual

9Said Aqil Husin al-Munawwar, Hukum Islam dan Pluralitas Sosial (Cet. I ; Jakarta: Penamadani, 2004), p. 5

${ }^{10}$ Abdurrahman Wahid, et.al., Kontroversi Pemikiran Islam di Indonesia (Bandung : Rosda Karya, 1991), p. 229 worship, among other things, for example, jihad must be prioritized over ritual worship, prioritized by experts in science over worship experts, and prioritized for peace for people who quarrel rather than shadaqah. ${ }^{11}$

In defining worship, it should be broad, so that it can include various types of deeds which often do not cross one's mind, that such actions have been made by Islam as a form of worship. Even the worldly deeds of a Muslim can be considered as jihad, if those actions are based on sincere intentions and always remembrance (remembering) Allah SW'T. ${ }^{12}$

When analyzed more carefully, the prayers, zakat, fasting and hajj, which have become routine practices of Indonesian society, are concrete evidence of the absorption of Islamic law in Indonesia in the field of worship,

\footnotetext{
${ }^{11}$ Umar Syihab, Hukum Islam dan Transformasi Pemikiran (Cet. I ; Semarang : Dina Utama, 1996), p. 104

${ }^{12}$ Yusuf al-Qardhawi, Al-Waqt Fiy Hayat alMuslim. Diterjemahkan oleh Bahrum Bunyamin dengan judul, Manfaat dan Nikmatnya Waktu dalam Kehidupan Umat (Bandung : Gema Risalah Press, 1998), p. 61
} 
although in practice it is still dominated by Syafi'iy fiqh.

The four forms of shari'ah worship mentioned above, which most seem to characterize the practice of Islamic law in Indonesia, are zakat and pilgrimage. Indonesia is one of the countries where every year the number of prospective pilgrims is very large, so that the Indonesian people to carry out the pilgrimage, the rules and implementation are based on the rules set by the state.

\section{B. Absorption of Islamic Law in Indonesia in the Field of Public}

\section{Law}

The term public comes from the English word public which means general, society, country. The word public has actually been accepted as Standard Indonesian to become public, which means general, crowd, crowded. ${ }^{13}$ The appropriate equivalent is praja, which actually means the people, so that

13J.S. Badudu, Sutan Mohammad Zain, Kamus Umum Bahasa Indonesia (Jakarta : Pustaka Sinar Harapan, 2001), p. 1095 the term pamong praja, ${ }^{14}$ which means government serving the interests of all the people, was born.Furthermore, according to Kepmenpan No. 63 / KEP / M.PAN / 7/2003, public is all service activities carried out by public service providers as an effort to fulfill the needs of service recipients and the implementation of statutory provisions. ${ }^{15}$

Public Law is a law that regulates the public interest and its relationship with the government. For example, Criminal Law, State Administrative Law and Constitutional Law. ${ }^{16}$ The author in this sub-issue tends to focus on the discussion of criminal law, meaning the extent to which Islamic legal values color criminal law in Indonesia. In the discussion of figh, criminal law is termed Fiqh Jinayat, which regulates the provisions of punishment for murderers, thieves, adulterers, rebels, drinkers of khamr, and so on. The

${ }^{14}$ Syafi,I Djamaluddin Tandjung, Supardan Modeong, Ilmu administrasi Publik (Jakarta : Rineka Cipta, 1999), p. 17

${ }^{15}$ Lijan Poltak Sinambela, Reformasi Pelayanan Publik; Teori, Kebijakan, dan Implementasi (Cet. V ; Jakarta : PT. Bumi Aksara, 2010), p. 5

${ }^{16}$ J.C.T. Simorangkir, at, al. Kamus Hukum, (Cet. XIV ; Jakarta : Sinar Grafika, 2010), p. 136 
author agrees that the application of Islamic law for the perpetrators of this sin has not been implemented in Indonesia.

Mohammad Daud Ali in his book emphasized that although the application of Islamic law to the violations mentioned above has not been carried out in Indonesia, ${ }^{17}$ on the other hand, the principles of Islamic law are accommodated in the enforcement of criminal law in Indonesia. These principles include:

\section{The principle of legality}

What is meant by the principle of legality is the principle which states that there is no violation and there is no penalty before a law regulates it. This principle is based on the Koran surah alIsra (17): 15:

Translation:

Whoever acts according to the guidance of (Allah), then surely He does it for (salvation) himself; and Whoever

${ }^{17}$ Mohammad Daud Ali, Hukum Islam ; Pengantar Ilmu dan Tata Hukum Islam di Indonesia (Cet. V ; Jakarta : PT. Raja Grafindo Persada, 1996), p. 117 is astray Then Verily He is lost for (loss) himself. and a sinner cannot bear the sins of others, and We will not punish before We send an apostle.

Connected with a clause in surah alAn'am (6): 19:

Translation:

Say: "Who is the stronger the testimony?" Say: "Allah". He is a witness between me and you. and this Al Quran was revealed to me so that with Him I will warn (in the form of rules and threats of punishment) to you and to those who reach the Al-Quran (to him). Do you actually admit that there are other gods besides Allah? Say: "I do not acknowledge." Say: "Verily $\mathrm{He}$ is God Almighty and Verily I am free from what you associate (with Allah).

This legality principle has existed in Islamic law since the Qur'an was revealed.

\section{The principle of prohibition of transferring the blame to others. \\ This principle is found in various chapters and verses of the Koran, Q.S. al-An'am: 165, Q.S. Fathir: 18, Q.S. al- Zumar: 7, Q.S. al-Najm: 38, Q.S. al-}


Muddatsir: 38. In surah al-Mudatsir: 38, for example, it is stated that every soul is tied to what he is doing, and everyone will not bear the sins or mistakes made by others. In the verse 164 of the surah al-An'am, Allah Almighty states that every person who commits a crime will be rewarded with the crime he did. This means that you should never burden (sin) other people. From the verses mentioned, it is clear that one cannot be held responsible for crimes or wrongs committed by others. Since criminal liability is individual in nature, a person's guilt cannot be transferred to another person.

\section{The principle of presumption of innocence}

A person who is accused of a crime must be presumed innocent before the judge with convincing evidence confirms his guilt. A consequence that cannot be avoided from the legality principle is the presumption of innocence. According to this principle, all actions are deemed permissible, unless stated otherwise by a legal text. ${ }^{18}$ Furthermore, everyone is considered innocent for an evil act, unless proven guilt for a crime without any doubt. If a reasonable doubt arises, the accused must be acquitted. This concept has been placed in Islamic law long before it was recognized in positive criminal laws. Fourteen centuries ago our Master Muhammad (s). Said: Avoid for Muslims the punishment of hudud whenever you can and if you can find a way to release it. If the priest is wrong, it is better to be wrong in acquitting than wrong in punishing.

\section{Absorption of Islamic Law in}

\section{Indonesia in the Field of Private}

\section{Law}

The term private is a word that comes from private English, which means private, private, private, civil, and others. ${ }^{19}$ When associated with the word law, which means law, so that it is said

${ }^{18}$ Topo Santoso, Membumikan Hukum Pidana Islam ; Penegakan Syariat Dalam Wacana dan Agenda (Cet. I ; Jakarta : Gema Insani Press, 2003), p. 14

${ }^{19} \mathrm{John}$ M. Echols dan Hassan Shadily Kamus Inggeris Indonesia (Cet. XXX ; Jakarta : PT. Gramedia Pustaka Utama, 2008), p. 447 
to be Private Law, what is meant is Civil Law. The discussion of this paper is based on the subject of Islamic Law in Indonesia, so the authors examine the sub-discussion above by directing the understanding of the extent to which the application of Islamic law in Indonesia in the field of civil law.

Islam entered Indonesia in the I H or VII century $\mathrm{AD}$ brought by Arab traders. ${ }^{20}$ It is not an exaggeration if this era is the era in which Islamic law first entered Indonesian territory. However, it is important to note, as Martin Van Bruinessen said, the emphasis on the fiqh aspect is actually a recent phenomenon. In the earliest days of the development of Islam in Indonesia the emphasis was on Sufism. ${ }^{21}$ However, according to the author, this statement does not mean that jurisprudence is not

${ }^{20}$ Endang Saifuddin Ansari, W awasan Islam; Pokok-Pokok Pikiran tentang Islam dan Umatnya Jakarta : Rajawali Pers, 1991), p. 253.Bandingkan dengan Hasymi (ed), Sejarah Masuk dan Brrkembangnya Islam di Indonesia, (Bandung : al-Ma'arif, 1981).

${ }^{21}$ Amiur Nuruddin dan Azhari Akmal Tarigan, Hukum Perdata Islam di Indonesia ; Studi Kritis Perkembangan Hukum Islam dari Fikih, UU No. 1/1974 sampai KHI (Cet. III ; Jakarta : Prenada Media Group, 2006), p. 3 important considering that the Sufism that is developing in Indonesia is Sunni Sufism which places fiqh in a significant position in the structure of the Sufism building.

Some experts say that the Islamic law that developed in Indonesia has the Shafi'iyyah pattern. This is shown by historical evidence, among them, Sultan Malikul Zahir of Samudra Pasai was a well-known expert on religion and Islamic law in the middle of the XIV century AD.

Laws made in the Republic of Indonesia which are based on Pancasila, must pay attention to the sense of justice of the Indonesian people, especially Muslims who are the majority in number. If the law made does not take into account the sense of legal justice adhered to by the community, then the law will be rejected by the community where the law is enforced.

The enactment of Islamic law as positive law for Muslims in Indonesia, which is the majority in this country, is based on the philosophical, juridical and sociological values of the Indonesian nation. Therefore, the State is obliged to 
make Islamic law a positive law for Indonesian Muslims. Because basically the way of thinking, life view, and character of a nation is reflected in its culture and laws. ${ }^{22}$

In the author's opinion, the real evidence of the application of Islamic law in the field of civil law in Indonesia includes, first, Law no. 1 of 1974 concerning Marriage, which was ratified on 2 January 1974, and subsequently effective from 1 October 1975. Second, Law No. 7 of 1989 concerning Religious Courts. Third, the Compilation of Islamic Law, which was ratified under Presidential Instruction No. 1 of 1991 to the Minister of Religion to disseminate the Compilation of Islamic Law which consists of I on Marriage, Book II on Inheritance, Book III on Waqf. The Presidential Instruction was followed up by the Decree of the Minister of Religion No. 154 of 1991 dated 22 July 1991.

${ }^{22}$ Musthofa dan Abdul Wahid, Hukum Islam Kontemporer (Cet. I ; Jakarta : Sinar Grafika, 2009), p. 160

\section{Absorption of Islamic Law in}

\section{Indonesia in the Field of Ethics}

The Second Principle of Pancasila mentions just and civilized humanity. This expression suggests that the Indonesian nation is a civilized, ethical, moral nation. A nation that upholds ethics and morals. Even according to historical facts, the kingdoms that have existed in the archipelago, although their beliefs are still controlled by Hindu Buddhists, in practice their life is very concerned about and upholds ethical and moral issues.

Ethics, morals or morals are life terms that talk about good and bad values. Good and bad values can be related to human attitudes towards Allah, Rasulullah SAW., Themselves, family, society and also towards nature. If we talk about human attitudes towards Allah Almighty and His Messenger, which automatically involves the life order outlined by Allah and His Messenger to humans, the good and bad values will be reflected in human behavior itself. Whether humans accept it sincerely or reject it or is it capable of guiding people to noble morality, 
maintaining high morality, or preventing moral decadence in society. In short, humans as God's creatures must be willing and able to apply the values outlined by Allah and His Messenger, whenever and wherever they are. This is a manifestation that the Prophet Muhammad was sent only to perfect morals in a very broad sense. ${ }^{23}$

If we want to study Islamic law carefully, we will find many rules that are full of morality. In it we will find legal provisions that really foster noble morality, both individual morality and collective (group, community) morality. In Islamic criminal law, for example, there is a provision that a person who commits adultery (extramarital sexual relations) is punished with one hundred lashes in public (crowd) (Q.S. 24: 2). Adultery according to Islamic teachings is considered a heinous act and is the worst path taken by civilized humans (Surah 17: 32). Eating usury is prohibited because it is an injustice to the weak (Q.S. 2: 278-9). Creditors are to give leeway (without charging

\footnotetext{
${ }^{23}$ Ahmad Azhar Basyir, p. 136
}

interest) to debtors who are having difficulty repaying their debts at the promised time. If the debtor is truly unable to pay off his debt, the creditor should donate it (Q.S. 2: 280). Islamic law prohibits traders from reducing the buyer's rights, both in terms of size, scale and size (Q.S. 11: 85). The hadith of the Prophet teaches that slowing down to pay debts after maturity for a debtor who is already able, is an oppression (HR. Bukhari-Muslim). ${ }^{24}$

To maintain the safety of Muslims, the Koran regulates interfaith marriages in three places. In Surah al-Baqarah verse 221, it is prohibited for men to marry a Muslim Muslim, and a woman to marry a male Muslim. What is meant by idolatrous men or women are idolaters who associate partners with Allah. Including them are people who have religions other than Jews and Christians. The Koran forbids women believers from marrying unbelieving men (non-Muslims, regardless of their religion) (QS 60: 10.According to the Koran, men believers are allowed to

${ }^{24} I$ bid., pp. 137-138 
marry women who are experts of the book (Jewish or Christian) (QS 5: 5, but To be able to use the dispensation, three conditions are needed, namely having a strong faith, not worrying about being attracted to the religion of the wife, acting as the head of the family who can color Islamic household life, ensuring that their children are Muslim, namely following the religion of the father. These conditions cannot be fulfilled completely, so the male believer is not entitled to use the relief provided by the verse.

Law No. 1/1974, concerning marriage supports the provisions of the Koran. This is natural, because marriage according to law is based on the One Godhead. Religious laws regarding marriage are respected. Because we find the provisions in Article 2 paragraph (1) which clearly and clearly state that marriage is valid if it is carried out according to the laws of each religion and belief. On the basis of these provisions, for Muslims the provisions stated in the Q.S. 2: 221, Q.S. 60: 10, and Q.S. 5: 5. Believing women are only legally married to believing men. A male believer may marry a woman, a believer or an expert of the book with the conditions mentioned above. Islamic morality demands that Muslims accept these provisions willingly and in totality.

\section{CONCLUSION}

Based on the description above, several conclusions were drawn, namely:

Indonesia is a country with a majority Muslim population, so that the norms of Islamic law automatically characterize the life of Indonesian society. In the field of worship, the most concrete rules of Islamic law are those applied to the implementation of the hajj and zakat.

In the field of Islamic criminal law, it is true that the implementation of punishment for murderers, thieves, adulterers, and so on has not been implemented in Indonesia, however, the principles of Islamic criminal law are widely absorbed in the enforcement of positive law in Indonesia, among others, these principles are; the principle of legality, the principle of innocence, the principle of prohibition of transferring the blame to others. 
Application of Islamic law in the field of civil law, the author looks at Law no. 1 of 1974 concerning Marriage, Law no. 7 of 1989 concerning Religious Courts, and Presidential Instruction No. 1 of 1991 concerning the Compilation of Islamic Law (KHI). The three products of the law are evidence of the application of Islamic law in the field of civil law in Indonesia.

Indonesia is a country that upholds ethics and morals. And the most perfect ethical, moral, and moral teachings are the teachings of Islam brought by the Prophet Muhammad, so that the majority of ethical teachings in Indonesia are accommodated from Islamic teachings. And this is concrete evidence of the application of Islamic law in Indonesia in the field of ethics.

\section{REFERENCES}

Ali, Mohammad Daud, Hukum Islam ; Pengantar Ilmu dan Tata Hukum Islam di Indonesia Cet. $V$; Jakarta : PT. Raja Grafindo Persada, 1996

Al-Munawwar, Said Aqil Husin, Hukum Islam dan Pluralitas Sosial Cet. I ; Jakarta: Penamadani, 2004

Al-Qardhawi, Yusuf, Al-Waqt Fiy Hayat al-Muslim. Diterjemahkan oleh
Babrum Bunyamin dengan judul, Manfaat dan Nikmatnya Waktu dalam Kehidupan Umat. Bandung : Gema Risalah Press, 1998

Ansari, Endang Saifuddin, Wawasan Islam ; Pokok-Pokok Pikiran tentang Islam dan Umatnya. Jakarta : Rajawali Pers, 1991

Badudu, J.S., Sutan Mohammad Zain, Kamus Umum Bahasa Indonesia. Jakarta : Pustaka Sinar Harapan, 2001

Basyir, Ahmad Azhar, Refleksi Atas Persoalan Keislaman ; Seputar Filsafat, Hukum, Politik dan EkonomiCet. IV. Bandung: Mizan, 1996

Hasymi (ed), Sejarah Masuk dan Brrkembangnya Islam di Indonesia, Bandung : al-Ma'arif, 1981

M. Echols, John, dan Hassan Shadily Kamus Inggeris Indonesia Cet. XXX; Jakarta : PT. Gramedia Pustaka Utama, 2008

Musthofa dan Abdul Wahid, Hukum Islam Kontemporer Cet. I ; Jakarta : Sinar Grafika, 2009

Nasution, Harun, Islam Ditinjau dari Berbagai Aspeknya, Jilid I Cet. $V$; Jakarta : Universitas Indonesia Press, 1985

Nuruddin, Amiur, dan Azhari Akmal Tarigan, Hukum Perdata Islam di Indonesia ; Studi Kritis Perkembangan Hukum Islam dari Fikih, UU No. 1/1974 sampai 
KHI Cet. III ; Jakarta : Prenada Media Group, 2006

Santoso, Topo, Membumikan Hukum Pidana Islam ; Penegakan Syariat Dalam Wacana dan AgendaCet. I ; Jakarta : Gema Insani Press, 2003

Schachat, Yoseph, An Introduction to Islamic LawOxford : Oxford University Press, 1964

Simorangkir, J.C.T., at, al. Kamus Hukum, Cet. XIV ; Jakarta : Sinar Grafika, 2010

Sinambela, Lijan Poltak, Reformasi Pelayanan Publik; Teori, Kebijakan, dan Implementasi Cet. $V$; Jakarta : PT. Bumi Aksara, 2010

Syafi'i, Inu Kencana, Djamaluddin Tandjung, Supardan Modeong, Ilmu administrasi Publik. Jakarta : Rineka Cipta, 1999

Syarufuddin, Amir, Meretas Jihad ; Isu-Isu Penting Hukum Islam Kontemporer di IndonesiaCet. I ; Jakarta : Ciputat Press, 2002

Syihab, Umar, Hukum Islam dan Transformasi Pemikiran Cet. I ; Semarang : Dina Utama, 1996

Wahid, Abdurrahman, et.al., Kontroversi Pemikiran Islam di Indonesia. Bandung : Rosda Karya, 1991

Yafie, Ali, Fungsi Hukum Islam dalam Kehidupan Umat, dalam Amrullah Abmad, Dimensi Hukum Islam Dalam Sistem Hukum Nasional
Cet. I ; Jakarta : Gema Insani Press, 1996

Yafie, Ali, Menggagas Fiqih Sosial ; Dari Soal Lingkungan Hidup, Asuransi hingga Ukhuwah Cet. II ; Bandung : Mizan, 1994 